\title{
Turmoil, Hubris, and Hope: Recent Retrospectives on the Great Society
}

\section{Bell Julian Clement}

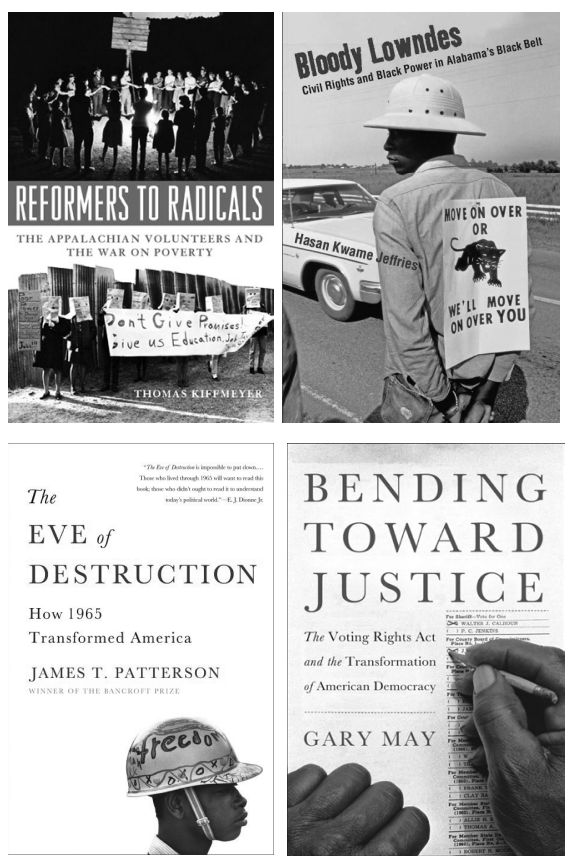

REFORMERS TO RADICALS: The Appalachian Volunteers and the War on Poverty. By Thomas Kiffmeyer. Lexington: The University Press of Kentucky. 2008.

BLOODY LOWNDES: Civil Rights and Black Power in Alabama's Black Belt.

By Hasan Kwame Jeffries. New York: New York University Press. 2009.

THE EVE OF DESTRUCTION: How 1965 Transformed America. By James T. Patterson. New York: Basic Books. 2012.

BENDING TOWARD JUSTICE: The Voting Rights Act and the Transformation of American Democracy. By Gary May. New York: Basic Books. 2013. 


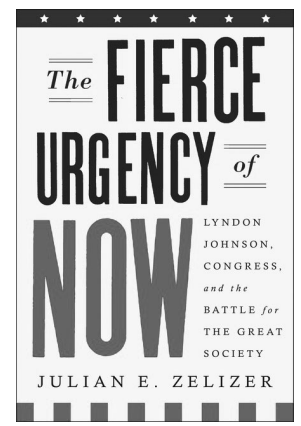

THE FIERCE URGENCY OF NOW: Lyndon Johnson, Congress, and the Battle for the Great Society. By Julian E. Zelizer. New York: Penguin Press. 2015.

The current round of fiftieth-anniversary celebrations of the events of the 1960s are a reminder that the American civic conversation is still framed in Great Society terms. Lyndon Johnson's Great Society effort-comprised of nearly two hundred major domestic measures during his five years in office-restructured policy in the areas of health, education, immigration, urban governance, mass transit, public housing, and the stewardship of natural and cultural resources, in addition to epochal civil rights reforms. Whether viewed as the point at which the American experience veered off course or as a moment when the nation renewed its commitment to equality and civic excellence, the Johnson years identified goals and launched programs that remain at the center of domestic policy arguments. We delve into the Great Society record in hopes of understanding what produced the Sixties' great burst of political creativity and what led it to fade and also to seek a basis for judging the value of the effort. The five works reviewed here inquire after the social and political conditions that made enactment of the Great Society program possible and, ultimately, led the policymaking enthusiasm to subside. They explore the intertwined roles of activism at the grassroots and in Washington, first in facilitating the passage of the landmark legislation of those years (paying particular attention to the Economic Opportunity Act of 1964 and the Voting Rights Act of 1965), and then in working out its implementation in American communities.

James T. Patterson's The Eve of Destruction reminds readers of the tumult of 1965, the year in which the Eighty-Ninth Congress convened and Lyndon Johnson launched his Great Society in earnest. The year opened with the fulsome promises of LBJ's first State of the Union address as president in his own right. It was darkened by the February launch of Operation Rolling Thunder (the U.S. bombing campaign against North Vietnam), the first landing of U.S. Marine combat forces at Da Nang in March, and the fateful decision to escalate American involvement in the Asian ground war in July. The year saw the assassination of Malcolm X in February, the mauling of civil rights activists in Selma the next month, and the explosion of Watts in August. Yet the same year also witnessed federal legislative achievement of a magnitude not seen since the heyday of the New Deal, including the creation of Medicare and Medicaid, passage of the landmark Elementary and Secondary Education (ESEA) and Voting Rights (VRA) acts, and enactment of fundamental immigration reform.

Patterson describes 1964 as "a buoyant time . . . a prosperous year that promoted extraordinarily high expectations about the future" (1). They were "the most hopeful times in all the years since Christ was born" in Johnson's own illadvised Christmas 1964 phrasing (ix). Against this rosy background, Patterson 
sees 1965 as a "hinge" year, the year "when America's social cohesion began to unravel and when the turbulent phenomenon that would be called 'the Sixties' broke into view" (xi). What evaporated over those twelve months was, essentially, that broad public consensus on American goals at home and abroad which is the condition precedent for national policymaking. By year's end, opines Patterson, "the once powerful political clout of liberalism was no more" (244).

In Patterson's view, the transformation was driven by two factors. The first was the Vietnam escalation, which "[m]ore than any other event of the year ... spurred the polarization that characterized the Sixties in the United States" (89). Patterson traces the devolution to the bitterness brought about by Johnson's indecision about American war aims and his furtiveness - the choice to develop Vietnam policy in secrecy rather than open the issue to public dialogue and congressional debate. The other source of polarization for Patterson was "the fracturing and enfeebling of the nonviolent, interracial civil rights movement" (225). The conflagration in Watts "left the once proud and luminously effective civil rights movement in a state of disarray from which it never recovered" (179) and began the shift in national attention from the War on Poverty to the war on crime. New social movement militancy confirmed many Americans' view that "an inexorably expanding rights-consciousness - a 'rights revolution' - was undermining a durable and long-cherished culture of rules and responsibilities" (xi).

The hinge is a useful device for historians seeking to focus an historical narrative narrowly, but, as Patterson recognizes, it is historiographically suspect. While the year 1965 saw significant developments in both African-American activism and Vietnam policy, alternative inflection points are readily discernible. August 1964, for example, saw the exclusion of the Mississippi Freedom Democratic Party (MFDP) delegation from the Democratic National Convention and the abdication of congressional responsibility in the Gulf of Tonkin resolution, both portentous events. If the civil rights movement splintered, Watts was not the cause. And as for Vietnam, large majorities supported the president's policies late into the decade.

The difficulty of the hinge device is that in narrowing historical perspective it leads to misidentification of the sources of change. The change agents that Patterson identifies are, on a longer view, themselves only symptoms of broader, if more subtle, sea changes. For one, there is simple demography, rarely given its due in accounts of the 1960s. The overlooked common denominator among the black liberation, student, anti-war, and women's liberation movements is the youth of their participants. The availability of large numbers of relatively affluent young people primed to critique their parents' society goes far to explain Sixties turmoil, as is suggested by the global youth eruptions-Tokyo, Paris, Mexico City—of 1968.

The year 1965 is less a hinge - which suggests a marked change in direction - than a next phase, a predictable development from immediately preceding events. In brief, the year 1965 was different from 1964 because things got harder. The lofty promises of 1964 now had to be translated into program. The "easy" 
battles of the civil rights movement against de jure segregation were replaced by the more difficult struggle to crush de facto Jim Crow. Instead of the cakewalk they had anticipated, U.S. Marines arriving in Vietnam confronted the ferocious determination of the Vietcong. And, as Patterson notes, Lyndon Johnson's "fabulous Eighty-Ninth" Congress was pouring out vast new domestic programs with little thought for the governmental infrastructure that would be necessary to implement them. The consequences of this mix of activated citizenry, overblown policy promises, and administrative gridlock were predictable: it is surprising that civil society held together as well as it did.

The Fierce Urgency of Now: Lyndon Johnson, Congress, and the Battle for the Great Society examines one of the chief motors of this Sixties turbulencefederal policymaking. Julian Zelizer examines the Johnson presidency from its 1964 triumphs in speeding John Kennedy's pending tax and civil rights bills through Congress to LBJ's resigned acceptance of deep spending cuts in Great Society programs in 1968 - the price extracted by congressional conservatives in exchange for the tax increase needed to fund his ruinous Vietnam policy. Zelizer retells this familiar story in order to challenge what he identifies as two "myths" about the political environment of the Johnson years. The first is that the 1960s represented "the apex of modern American liberalism," the political outlook that viewed activist national government "as a positive good" and that it was this favorable environment that enabled enactment of the president's program (3). Zelizer asserts that, to the contrary, in 1964 "liberalism was in bad shape, fragile and ineffective, beset on all sides by powerful enemies" (5). The second myth is that the Great Society was "the product of Lyndon Johnson's brilliant legislative prowess" (5) - a view, asserts Zelizer, that "overemphasizes the capacity of 'great men' to effect legislation by force of personality" and undervalues the "complicated ... political environment in which a president must operate" (7).

Zelizer suggests that in "seeking to understand how this historic burst of liberal domestic legislation happened" we should ask instead "what legislative conditions existed" to allow its success (8). He credits two factors in particular. The first of these was the effectiveness of the civil rights movement, which "placed immense pressure on legislators in both parties to pass laws that would benefit African Americans" (8). The second factor, argues Zelizer, was the liberals' landslide success in the 1964 election, which enabled them to break through conservatives' hold on Congress (8). Zelizer's framing is open to challenge. For one, if landslide margins in Congress were essential to Great Society success, how does he explain 1964-a banner year legislatively with the passage of the Kennedy bills and the launch of the War on Poverty?

More importantly, Zelizer's assertion about the "fragile" state of liberalism is not well defended here. That the Johnson years were, indeed, a "high tide" of American liberalism is suggested by the fact, noted by Zelizer, that LBJ himself "recognized that the moment for another New Deal had arrived" (62). Zelizer doesn't classify this as a liberal moment in part because he is mindful of potent conservative influences in Congress and in part because he views it, narrowly, as a 
product solely of "the energy, ambitions, and anger of the civil rights movement" (62). This formulation continues the unfortunate tendency to pop the civil rights movement out of its context as one piece in the complex structure of postwar liberalism, a structure that included a beleaguered left, peace activism, and a rising student movement, as well as still-potent unionism. Jointly, these movements created the liberal climate - the "culminating liberal moment" - in which effective civil rights initiatives and the larger Great Society program emerged.

Zelizer touches on but does not explore three other factors that had a lively role in shaping the Great Society, and especially Johnson's "fabulous EightyNinth" Congress. The first of these are the repercussions of the removal of the issue of de jure segregation from future congressional debates through the passage of 1964 and 1965 civil rights legislation. It was this development that cracked the hold of the conservative coalition of Republicans and Southern Democrats on Capitol Hill. Zelizer asserts that this disruption changed the political dynamic within Congress only in its dealings with other civil rights legislation. But in disposing of the segregation issue, the civil rights legislation broadly removed the basis for the bargains that had held the conservative coalition together-conservative Republicans offering their support for Jim Crow in return for Southern Democrats' votes on federal spending programs that Republicans preferred to kill. As Zelizer himself shows, the coalition's collapse allowed for passage of the ESEA with substantial southern support.

Second, Zelizer describes, but does not include in his argument, the role of bipartisan cooperation in the Eighty-Ninth Congress. To an extent entirely exotic to twenty-first century eyes, congressional Democrats and Republicans of the Johnson years worked together. Zelizer depicts an institutional culture that enabled effective contributions from the minority and led to enacted bills. Everett Dirksen (R-IL) in the Senate and William McCulloch (R-OH) in the House were crucial partners in passing civil rights legislation. Wilbur Mills (D-AR) managed to incorporate both Republican, Democratic, and White House bills in the measure that produced Medicare.

Finally, although he fully credits LBJ's legislative dexterity, Zelizer leaves out what was surely the president's most crucial contribution to the Great Society: his willingness to undertake it. Whichever of history's whispering ambitions Johnson was responding to, he chose to put forward a program of startling scope and aspiration. One can imagine a very different outcome under any other Kennedy successor (look only at the previous century's Johnson). Lyndon Johnson cannot be accounted for as a force in history by reference to his legislative prowess alone.

Where Zelizer surveys the Great Society legislative process as a whole, Gary May's Bending Toward Justice: The Voting Rights Act and the Transformation of American Democracy takes a focused look at one of its most significant achievements. His volume spans the more than five decades between civil rights activists' efforts to register Selma, Alabama voters in the early 1960s to presentday vote suppression controversies. May brings private citizens, the force that created the movement, back into the picture. His detailed telling reanimates the 
internal complexity of the civil rights movement and the fragile contingency of the events that in the end yielded the Selma confrontation. The account also raises, although it does not address, the question of grassroots action's influence in shaping the VRA.

It is impossible to tell history in its full complexity, so it is small wonder that the stories we tell about social change tend to reduce its processes to a series of negotiations among leading factions. But efforts vast and various are needed to create the conditions under which milestone laws like the VRA emerge. As May reminds us, Selma's battle for the ballot didn't begin on the Edmund Pettus Bridge. Selma residents C.J. Adams and Samuel and Amelia Boynton had carried the burden since reinvigorating the Dallas County Voters League in the 1930s. Bernard Lafayette arrived in Selma in 1962 as a lone scout for the Student Nonviolent Coordinating Committee (SNCC) and was followed by a SNCC project team, which settled in the city during 1963 and 1964. May's account is a reminder that moments like Selma occur only when citizens are moved to risk their peace and perhaps their lives in desperation to bring about a new order.

May's study also unsettles any remaining notions of the civil rights movement as a monolithic effort. Different factions had different visions of its goals. Nurtured by veteran activist Ella Baker, SNCC workers were community organizers striving to create local organizations that would outlast SNCC's sojourn in the community. From SNCC's vantage, Southern Christian Leadership Conference (SCLC) operations were shallowly opportunistic. SCLC campaigns disrupted the difficult and tedious work of organizing and exploited local developments for their impact on the national scene. SCLC's reliance on Martin Luther King Jr.'s celebrity status and on "publicity stunts" like the Selma-to-Montgomery march resulted in a "movement" that shut down as soon as klieg lights were switched off, leaving the locals to deal with the mess left behind. If some of these differences were complementary and productive, ultimately they created an internal dynamic that helped break the movement apart.

Detailed accounts like May's disrupt lazily teleological interpretations of social action. It is difficult to recreate the contingency of history-the fact that actors do not know how things will work out and operate unaware of the harmonies detected in hindsight — but it is that contingency that gives the narrative interest and that May is able to redeem. Selma was anything but a planned action. King and SCLC were peripheral to many of the developments there, and happenstance shaped much of their involvement with the rest. King arrived in Selma at the invitation of local activists on January 2, 1965 and by mid-February he was ready to move on. Local white leaders had moderated their policies and a federal court had issued an order protecting the voter registration process. King suspected that events in Selma "had run their course" (72). SCLC's return to Selma was the result of the fatal shooting of twenty-six-year-old black army veteran and civil rights activist Jimmie Lee Jackson by the police. Speaking to a mass meeting in a moment of grief and rage following Jackson's February $26^{\text {th }}$ death, King lieutenant James Bevel called for a march on Montgomery. The call 
had not been planned or cleared by King (81). In fact, on the morning of March $7^{\text {th }}$ King called the event off, fearing violence (83). Preparations continued due to miscommunications with his SCLC aides on the scene and King acquiesced in the fait accompli shortly before the marchers set out that afternoon. King, preaching in Atlanta, was not present.

The saga of the civil rights movement provides Americans some of our most treasured stories about ourselves. We cherish the Selma legend-its lesson that humble but righteous citizens can achieve morally necessary changes in the nation's social contract. This emotional attachment makes it necessary to scrutinize carefully whether, and how, citizen action actually does affect policy development. May joins the consensus in assuming that events in Selma were important to VRA enactment, that "by provoking Sheriff Clark into committing mayhem ... King had aroused the nation and Congress to action," but he doesn't add to understandings of how, precisely, that influence operated (149). That Johnson was determined to pass voting rights legislation well in advance of the events in Selma is evidenced by his communications with his attorney general as early as July 1964. The administration draft of the bill was complete on March 1, 1965, prior to the Selma confrontation. May does not provide evidence that movement spokespeople had much of a role in shaping the bill. Although Johnson did communicate with King about the bill's provisions, the administration's major concern described here was to ensure that the measure would pass constitutional muster, given the Article 1, Section 2 assignment of the authority to determine voter eligibility to the states.

The images of the police riot on the Edmund Pettus Bridge, broadcast that evening to more than forty-eight million viewers, shocked public opinion and drew hundreds of Americans to Selma to join in the completion of the march. But would events in Congress have been significantly different had the Selma campaign never happened? Johnson's determination to push a voting rights bill through Congress seems clear, and in the wake of his 1964 landslide he had the votes to do it. The question remains unanswered.

Works by Thomas Kiffmeyer and Hasan Kwame Jeffries turn attention away from Washington, D.C. to examine Great Society policy implementation on the ground in Appalachia and Alabama. Kiffmeyer's Reformers to Radicals: The Appalachian Volunteers and the War on Poverty makes an important contribution to an under-researched area of the Great Society endeavor: its engagement with rural, as well as urban, poverty. The Great Society effort in Appalachia operated initially through the Council of the Southern Mountains (CSM), a venerable Progressive era organization (founded in 1913) that received one of the earliest War on Poverty grants. In late 1963 the CSM kicked off a Kentucky school rehabilitation program, relying on the labor of students from colleges in the region. Student work crews, calling themselves Appalachian Volunteers (AVs), fanned out into the first projects in Harlan County, Kentucky in January 1964. The first War on Poverty grant arrived in December 1964 and the effort mushroomed. AV chapters sprouted at colleges around the region and the effort 
drew national attention: by mid-1965 Students for a Democratic Society members were working in the region and a SNCC veteran had been hired as AV assistant director. By the summer of 1966 the organization fielded five hundred workers in Appalachian communities.

Great Society funding made possible a broader, more intensive organizing effort than CSM funding alone could have supported. In Kiffmeyer's account, a key result was that AVs had enough time in the field to rework their thinking about the nature of Appalachian problems. The CSM had traditionally espoused a strategy of cooperation, working with powerbrokers in the mining industry and local governments to address mountain poverty. Youth workers initially adopted their sponsor organization's analysis, including its "culture of poverty" diagnosis, which held that mountaineers' isolation and dysfunctional culture were the main factors in their poverty. The appropriate prescription, thus, was education and integration into the mainstream. AVs initially targeted Appalachian children with "cultural enrichment" activities and school facilities rehabilitations.

As the enormity of Appalachian troubles came into focus it quickly became clear to AV field workers that painting schoolhouses would not be enough. As one volunteer observed, "there are so many problems we're not the solution to" (133). "Culture of poverty" thinking was displaced by a new, radical analysis that understood Appalachia as "colonized," exploited territory. Volunteers redirected their eff orts to school system reform, welfare rights, and anti-strip mining legislation. They also moved away from the CSM pattern of cooperation with area mining interests and political machines: "[c]onfrontation became the new AV strategy" (135). Formalizing this ideological parting-of-the-ways, in May 1966 $\mathrm{AV}$ workers split from the CSM and established themselves as the Appalachian Volunteers, Inc.

Operating as an independent, radicalized organization, the AVs rapidly alienated both the communities they attempted to serve and local power structures. Volunteers barged into mountain towns-shaggy-haired men and mini-skirted women-blithely insensitive to the mores of these conservative communities. Worse, despite the evolution of their understanding of Appalachia, AVs never overcame the missionary zeal that marked their early forays into "cultural enrichment." Continuing to view mountaineers with cloaked condescension as victims of cultural deprivation, the young activists proposed "answers" to the Appalachian "problem" without having listened to residents' own views. AVs may have aspired to build the New Jerusalem amid Kentucky's green and pleasant hills, but the locals, as one AV noted, simply "longed ... to be middle class Americans" (210). The AVs' increasingly radical agenda outran its support in the community. "In many cases," in the view of one observer, "the program seemed to belong to the Volunteers rather than the community" (153).

The AVs' radicalization and new tactics of confrontation also ran afoul of regional stakeholders intent on maintaining stability and the status quo. The organization ultimately collapsed under aggressive repression from local and state governments: Pike County arrested AV officials on charges of sedition, the 
Kentucky Un-American Activities Committee investigated the organization for subversive activities, and area governors vetoed further War on Poverty funding for the effort. By the summer of 1970 the organization was defunct.

But the organization was not gone without a trace. The combination of federal support and local activism left a lasting mark in a raised consciousness and new militancy among the local people. As the AVs characterized it, before the start of their effort "the primary words used to describe the isolated Appalachian Mountaineer were apathetic, unmotivated, uninspiring, culturally deprived ... At the present time we are hearing him described as activist, trouble-maker, organized, impatient, frustrated, and in some cases angry (168)." After the disbanding of their own organization many of the AVs returned to work with the CSM, bringing their radical perspectives and goals with them.

Hasan Kwame Jeffries's Bloody Lowndes: Civil Rights and Black Power in Alabama's Black Belt provides a nuanced portrait of the marriage between federal policy initiatives and local activism in the battle to dismantle Jim Crow, focusing on the months from March 1965 through November 1966 when SNCC workers, led by Stokely Carmichael, were active in Lowndes County, Alabama. The challenge to white supremacy in Lowndes-long quiescent under the oppressive violence that had earned it its menacing moniker - came in March 1965, a few days before the confrontation on the Edmund Pettus Bridge, when a group of black citizens presented themselves at the county courthouse to register to vote. Denied, they formed the Lowndes County Christian Movement for Human Rights (LCCMHR). Simultaneous with this indigenous development, the county attracted the attention of SNCC activists looking for a new project after their displacement from Selma by SCLC. SNCC activists were in Lowndes by the end of the month, partnering with LCCMHR to register voters. The joint effort showed quick success. Attendance at mass meetings "skyrocketed," from a hundred participants at a late March meeting to nearly a thousand at gatherings two weeks later (69).

Still smarting from the Democratic National Convention's August 1964 rejection of the MFDP, SNCC activists promoted the idea of forming a third party to the LCCMHR. The proposal meshed well with residents' growing sense (the fruit of their months of organizing experience) that protests alone would not be enough to make change in the county and that political power was necessary. Lowndes activists formed what became the Lowndes County Freedom Party (LCFP) in April 1966. The party held its first nominating convention that May and fielded a ticket of candidates in the November county elections.

Jeffries is enamored of the LCFP, describing the party in terms of what it aspired to be but only briefly was: a party of working-class and poor people that engaged in collective decision making, chose its candidates for office from among the county's working class rather than its elites, and pursued a broad agenda including both civil and human rights. Although LCFP was not able to elect its candidates in November 1966, it captured 80 percent of the black vote and 42 percent of the total county vote, enough to require Alabama to recognize it as 
an official party. In 1970 the party - now merged with a statewide, interracial, independent party — elected a black man, leading local activist John Hulett, as Lowndes County sheriff. By 1980, African-American officials were in control of the Lowndes county commission.

But bright prospects quickly dimmed. The LCFP had few allies and class antagonisms loomed large. As Hulett saw it, the LCFP's "biggest fight ... is among our own people, like the ... school teachers and preachers who don't want any part in it because once the common Negro moves up he will become equal with him" (176-77). The political establishment was equally opposed. SCLC activists wanted black voters to stay inside the Democratic Party and help elect moderate whites, believing this was the "way ... to realize the full potential of re-enfranchisement" (167). Lowndes politics quickly reverted to business-asusual. Once in office Hulett used his evident political skills to establish himself as county boss. By the early 1990s, most of Lowndes's black citizens no longer bothered to vote.

Jeffries's telling makes clear that federal officials played an important, even preponderant, role in forcing the Lowndes county reforms of 1965-66. Significant advances were made only with the federal thumb on the African-American community's side of the scale, as is illustrated by the Lowndes voter registration drive. That effort stalled over the summer of 1965 in the face of county officials' intransigence but was revived spectacularly after August 14 when federal registrars arrived, less than a week after VRA passage.

Although local activists did make savvy use of federal resources, Jeffries's suggestion that locals controlled federal interventions in Lowndes - that local action "compelled" (78) federal responses or that it was local action that "drew Washington into the struggle" (118) - is not supported by evidence provided here. The Johnson administration strategy for national implementation of Great Society legislation likely determined federal moves.

But if local action did not directly shape federal policy or its implementation it was nonetheless essential for the achievement of national policy goals. Jeffries's metric for evaluating the events of 1965-66 in Lowndes is calibrated on changes in process rather than the achievement of discrete program outcomes. Activism in Lowndes transformed local politics, creating the African-American demand for civic inclusion to which federal efforts responded. The presence of federal registrars made possible the certification of hundreds of new voters, but it was LCCMHR and SNCC activism that ensured that the lines at the courthouse door would be long. For Jeffries, then, the impact of federal involvement "cannot be measured solely by the success rate of lawsuits or grant applications" (118). Rather, its value lay in the "grassroots organizing that federal involvement generated," producing "a wealth of experiential knowledge ... [that] helped transform black politics" (119) through "the slow and hard work of organizing" (141).

Each of these five works shows the Great Society years as a time when American policy aspirations, and hubris, confronted American political and administrative ability to deliver. Their findings suggest that there is plenty more 
information about what drove Great Society policymaking to be wrung out of the experience of the Johnson years.

The causes and consequences of policy initiatives and social movements are diffuse. Patterson and Zelizer assert the importance of specific developmentscivil rights activism, the 1964 landslide, Vietnam escalation - in explaining the period and its legislative legacy, but this narrow-gauge view is unsatisfying. These searches for discrete causal factors do not adequately credit or explore the larger currents in the liberal moment that shaped Great Society undertakings and their outcomes. Zelizer's close look at legislative dynamics should be matched by additional explorations of the politics of administering and implementing Great Society programs. There is, predictably, more work to be done in setting the Great Society in its mid-century context.

On the other hand, case studies by May, Kiffmeyer, and Jeffries point to interconnections between policy in Washington and activism in local communities but do not diagram the mechanisms by which these connections may have operated to change policy outcomes. These works point as well to the difficulty of achieving the Great Society goals, given the lack of political will to address structural causes of inequality. Clearer understanding of these processes may better illuminate the Great Society effort.

Perhaps most significant is the evidence of the diffuse nature of policy impacts that the Kiffmeyer and Jeffries studies provide. Experiences in both Appalachia and Alabama suggest that an essential measure of Johnson administration policies is that of their impact, for better or for worse, on the political education of citizens and the reshaping of civic expectations. The measure of Great Society success may be less a matter of the achievement of discrete program goals than of the extent to which the strength of communities - their civic competence - was enhanced in working toward them. 